\title{
Time and Timelessness
}

\author{
Ajahn Amaro ${ }^{1}$ \\ Accepted: 16 October 2020 / Published online: 29 October 2020 \\ (C) Amaravati Publications 2020
}

Opening the heart to the new day, with the pale, dim light of night-time, the moon and the stars slowly giving way to the rising sun, and color and form coming back into our perceptions, we bring attention to these cycles of day and night. A new day being born like a new breath; an inhalation being born. The day arises, a feeling arises, a thought swells up into being, does its thing and then fades away, whether it is a breath, a day, or a lifetime. But that which knows birth and death is not tied to birth and death. It's said the sun rises, but from the sun's point of view it doesn't rise. It is just doing its thing. It is because of the spinning of the earth that we speak of sunrise, but from the sun's point of view, it is not going anywhere. Similarly, if we shift our perspective to being the knowing, we are no longer attached to all the births and deaths, the successes and failures, and the springs and autumns. When you let go of that habit of grasping and identification, the heart abides in the position of the sun-central, bright, radiant, and unwavering.

Of course, all analogies are partial, imperfect. We could say, "But the sun is moving, spinning, hurtling through space as well," but for the purpose of this image, we take the sun in the context of this solar system as the symbol of wisdom-absolutely pure, with ocean-like compassion, the wisdom, the awareness of your own heart. When refuge is taken in the Buddha, awareness has the central position; taking refuge in the Buddha is being that awareness. The planets, asteroids and moons all spin and circle round it. They come and go and change and modulate, but that which is at the center is vast, steady, bright, and all the comings and goings happen around it. Because we are attached to the surface of the earth, we say that the sun rises and sets. Those

Excerpted from The Breakthrough by Ajahn Amaro, Amaravati Publications, 2016.

Ajahn Amaro

ajahn.amaro@gmail.com

1 Amaravati Buddhist Monastery, Great Gaddesden, Hemel Hempstead, Hertfordshire HP1 3BZ, UK who are attached to the body and personality say they are born and die. If you let go of that attachment to the body and personality, let go of the surface of the earth, take the position of the sun of wisdom, then what is the difference between the birth of a breath or a thought, and the perception of a body being born and a body dying? Our heart knows there is no difference. How could there be?

Let go of attachment to the body, to personality, to feelings of "I am." By letting go of self, by not creating an identification, an individuality, an "I," we are not creating bondage to the feeling of self. Let go of the sense of location. Let go of the feeling of place, recognizing, awakening to the fact that awareness is unlocated. Non-locality is the nature of the mind. It does not exist fixed in any one place. Space does not apply in the realm of the mind, the namma khandha $\bar{a}$. Here, there, everywhere, nowhere- - "where" does not apply. Let go of self, let go of place, and let go of time. In the Bhaddekaratta Sutta (M 131) the Buddha describes the ideal abiding, the ideal solitude. One who is wise lets go of thoughts of the past, lets go of thoughts about the future, and lets go of creations about the self here in the present moment. This is the ideal solitude, the ideal abiding, the ideal security of the here and now, of the paccuppanna dhamma, the ever-present dhamma.

When the heart rests in this quality - this awareness, vijja this knowing, attentive to the present reality - there is letting go of time. A conditioned mind habituated to Monday, Tuesday, Wednesday, to four o'clock, five o'clock, six o'clock, tends to see the past as solid reality stretching off into the infinite behind us. It creates the future, stretching off endlessly ahead of us. Dates that are still to come seem like real days, real months, real years, while the present seems like an insignificant little sliver, squashed between the vast and incalculable past and future, back to the Big Bang and beyond, off into the infinite possibilities of what is to come. This little sliver, this tiny unimportant moment between a vast past and a vast future, may seem insignificant, nothing very much. But this is simply our conditioned perception of time.

When there is wisdom we bring attention moment by moment to the felt experience of this life. There is a watching, a 
contemplating of how the world is formed, how life is experienced and shaped. We see the past is a memory, constructed here and now. The future is an imagined fantasy. Future and past - these words refer to formless potentialities, concepts that are generated and fabricated here and now. The image of the past, the memory of the past arises here and now. The imagined future is here and now. And the closer we look, the closer it is seen that the present is actually an infinite plain of being - the future and the past are insignificant little threads dangling in the breeze like broken spider webs, nothing very much at all. The absolute reality of Dhamma, the very fabric of nature, is here and now. Dhamma is sanditthiko, apparent here and now, akaliko, timeless, paccuppanna, ever-present. There is never any moment other than this moment.

It is interesting that the ancient Greeks had two gods of time. Chronos is the god of linear time, represented by an infinite straight thread stretching from the infinity of the past to the infinity of the future. Chronos is the god of the changing seasons, the coming and going of days and nights and the turning year. But Kairos is the god of the present moment. Kairos was represented by an infinite plain (or plane) through which the thread of Chronos passes; an infinite sheet, a vast, incalculably broad plane of the present through which the thread of linear time passes. This present moment which each of us experiences uniquely is where the infinite plane of Kairos and the infinite thread of Chronos meet each other. This present is where time and timelessness meet. T. S. Eliot expressed this wonderfully in The Dry Salvages, in his Four Quartets:

Men's curiosity searches past and future

And clings to that dimension. But to apprehend

The point of intersection of the timeless

With time is an occupation for the saint-

No occupation either, but something given

And taken, in a lifetime's death in love,

Ardour, selflessness and self-surrender.

This is a poetic way of speaking: "To apprehend the point of intersection of the timeless with time is an occupation for the saint" - or for the average Buddhist meditator. When we gather together to chant, to meditate, that is linear time intersecting with the infinity of the akaliko dhamma, the timeless reality, sanditthiko, apparent here and now, paccuppanna, ever-present.

"To apprehend the point of intersection of the timeless with time," the conditioned and the unconditioned - this is the task. Moment by moment, day by day, the timeless meets with the time-bound, with the attributes of the seeming self-this body, this personality, this name, this role in society. Who am I? What is the room I live in? My role as a retreatant, as a monastic, as a listener, as a speaker... is what? Those personal qualities meet the fundamentally non-personal. The role of space, me sitting in my spot here on the central cushion, you in your spot, your mat, your place; this is the reality of threedimensional location meeting the non-locality, the unlocated quality of mind. This is the task: to attend to this meeting point of self and not-self, time and timelessness, place and placelessness. This is the mysterious Middle Way where we respect both those realities. If there is clinging to the unconditioned or the formless, there is a loss of harmony, a loss of attunement to the realm of form. If there is clinging to the realm of form, identity and time and place, there is a loss of attunement to the timeless reality. The Middle Way is to attend to both; to the meeting point, the mysterious balancing point of the conditioned and the unconditioned, the created and the uncreated.

The word the Buddha coined to refer to himself is Tathägata. It is composed of two parts: "tatha" or "tath" which means "such" or "thus", and "gata" or "āgata" which mean, respectively, "to go" or "to come." The two halves together make Tathāgata, but as you can see, there is an inherent ambiguity in the word. For millennia there has been a debate over whether the Buddha meant "tath-ägata" (come to suchness, come to thusness, one who is totally immanent) or "tathä-gata" (one who is gone to suchness, utterly gone, transcendent). Is the Buddha principle totally here or totally gone? Is it immanence, embedded, embodied in the living world, the sense world; or is it totally transcendent, beyond, utterly unentangled? In Pali, the " $a$ " at the beginning of a word means it is negative, so gata means to go, àgata means to come. What did the Buddha mean? Why did he choose this word to refer to himself? Did the Buddha mean totally "here" or totally "gone"?

The Buddha was very fond of wordplay and double meanings. It seems that he coined this word deliberately because of its ambiguity. It means both totally here and totally gone; utterly immanent, fully attuned to the sense world, to earth, water, fire and wind; but giving them no footing-utterly transcendent, unentangled. So the Buddha principle participates fully and harmoniously in the sense world, attuned to earth, water, fire and wind; to conditionality; to sights, sounds, smells, taste, touch, thought, emotion. It is completely attuned, heartfully in harmony with all things, and yet is completely transcendent of all things; simultaneously utterly unentangled, without conflict, without confusion, without division-totally here, totally gone, heartfully participating and totally equanimous, unidentified, unattached. To the thinking mind, this can seem bewildering, but the heart knows that Middle Way, that point of intersection. So we train ourselves to trust that. This is the occupation for the practitioner, the saint, one given to sanctus, peace.

"Something given and taken"; we give our attention to this moment and we receive the gift of this moment, the gift of Dhamma-letting go of self, giving our attention, receiving the presence of the reality of the Dhamma itself. We receive 
that presence "in a lifetime's death, in love, ardour, selflessness and self-surrender."

When the left and right eyes operate in a balanced way, they give us a sense of the three-dimensional world. So too, the eye which sees the conditioned and the eye which sees the unconditioned together give us a realistic orientation in the world of form and the world of the formless. Sustaining and maintaining a respect for both realities is what orients the heart, helps us to know and sustain that Middle Way, being that middleness itself. The thinking mind can flounder and become bewildered. But we don't have to figure it out. Balancing on a bicycle or a tightrope is not a conceptual activity; it is a whole-body learning. Finding the Middle Way is not a conceptual learning; it is a whole-body, a whole-being learning, a whole-being training.

When we find that point of balance, when that Middle Way is embodied, present, known, this is the great delight of the heart. There is a quality of freedom and spaciousness. We can really enjoy our life. In the verses of Hui Neng, the Sixth Patriarch of the Ch'an Buddhist school of China, it is said:

In this moment there is no thing that comes to be, in this moment there is no thing that ceases to be, thus in this moment there is no birth and death to be brought to an end. Therefore this moment is absolute peace; and though it is just this moment, there is no limit to this moment and herein is eternal delight.

Publisher's Note Springer Nature remains neutral with regard to jurisdictional claims in published maps and institutional affiliations. 